The Canadian Journal of Higher Education, Vol. XXIII-3, 1993

La revue canadienne d'enseignement supérieur, Vol. XXIII-3, 1993

\title{
In the Shadow of the Tower: The View of the Undergraduate Experience
}

\section{IAN M. GOMME," MARY P. HALL, \& TERRY J. MURPHY*}

\begin{abstract}
This paper reports the initial findings of a survey $(\mathrm{N}=388)$ conducted in Winter 1991 focusing on the quality of the academic experience for Arts and Science students at a medium size post-secondary institution in eastern Canada. Our purposes are: 1) to set out the context in which undergraduates conduct their academic work, 2) to document what their experience entails, and 3) to present some of their perceptions of the higher education process. While most students have vocational goals in mind, they are also keenly interested in acquiring a solid general education. Undergraduates attend most of their classes, are heavily committed to completing their programs, and work quite diligently in pursuit of their goals in the face of what many of them consider to be heavy workloads. They are not, however, completely satisfied with the services that they receive in return for their tuition fees and for Canadians' tax dollars. While satisfaction levels vary with the type of services provided, it is clear that there does exist substantial room in which institutions can make improvements. Specifically, our data suggest that the primary goals of universities seeking to better the undergraduate

* Memorial University of Newfoundland

The project upon which this article is based was funded initially by a grant provided by Dr. Michacl Staveley, Dean of Arts, Memorial University. Without his support, the study would not have been possible. Funding from the Social Sciences and Humanities Research Council of Canada provided assistance with data analysis and with the writing of this paper. We would also like to acknowledge the valuable advice on project design and instrumentation provided by Dr. Sid Gilbert, University of Guelph.
\end{abstract}


experience should be to encourage more effective teaching and its evaluation, to reduce class sizes, to increase formal and informal interaction among faculty members and students, to improve the quality of academic advising, and to support the creation of more equitable financial assistance programs for students.

\section{Résumé}

Cet article présente les premiers résultats d'une enquête $(\mathrm{N}=388)$ menée durant l'hiver 1991 portant sur la qualité de l'expérience universitaire d'étudiants en arts et en sciences inscrits à une institution de moyenne importance dans l'est du Canada. Nos intentions sont: 1) d'établir le contexte dans lequel les étudiants accomplissent leur travail scolaire, 2) de documenter en quoi consiste cette expérience et 3 ) de décrire quelques-unes de leurs impressions sur le système d'éducation supérieure. Bien que la plupart des étudiants poursuivent des buts professionnels, ils s'intéressent aussi vivement à acquérir une éducation générale à bases solides. Les étudiants de premier cycle assistent à la plupart de leurs cours, se sont voués à compléter leurs études, et travaillent diligemment afin de réaliser leurs buts malgré ce que beaucoup d'entre eux estiment être des programmes exigeants. Toutefois, ils ne sont pas entièrement satisfaits des services qu'ils reçoivent en échange de leurs frais de scolarité et des impôts prélevés aux Canadiens. Alors que le degré de satisfaction varie selon les services offerts, il est clair que des améliorations s'imposent dans plusieurs domaines. Plus précisément, nos donnés suggèrent que les universités cherchant à améliorer l'expérience des étudiants au niveau du premier cycle devraient se proposer comme buts prioritaires d'encourager un enseignement plus efficace et de mieux l'évaluer, de réduire la taille des classes, de favoriser l'interaction formelle et informelle entre les professeurs et les étudiants, d'améliorer la qualité des services d'orientation scolaire, et de promouvoir la création de programmes d'aide financière plus équitable pour les étudiants.

\section{Introduction}

The measurement of quality and excellence in higher education is a popular and desired objective. Gauging the instructional performances of universities, however, is also a controversial undertaking, largely because the strategies for meaningfully achieving such worthy ends are neither straightforward nor inexpensive (Webster, 1990). Concerns over the quality of the teaching and learning environments provided by universities have been given voice in the past few years by several rather unflattering best sellers. Bloom's Closing of the American 
Mind (1987), Sykes' ProfScam (1988), and most recently Smith's Killing the Spirit (1991) have, to say the least, cast the ivory tower in a cloak of shadow. These scathing portraits of academe aside, the work of higher education scholars in the United States (Astin, 1985; Boyer, 1987, 1990) continues to emphasize the existence of room for improvement in the quality of American postsecondary education.

By no means have concerns for quality in higher education been ignored in Canada. In 1990-91, the Canadian Association of Colleges and Universities sponsored a Commission of Inquiry on University Education. Headed by Stuart Smith, the central orienting interests of the commission included relevancy, teaching performance, quality of student learning, accessibility, and the role of university education in Canadian society more generally. Immediately following the release of Smith's report (1991), Canadians were treated to a full edition of Maclean's (October 21, 1991) in which the magazine's staff used its own 'measures of excellence' scale to rank various Canadian institutions of higher learning. The issue of Maclean's was the second highest seller in the magazine's history and it now produces a 'university issue' on an annual basis (McMaster Courier, June 16, 1992).

Despite the massive expenditures on universities, despite the enormous numbers of people who are recipients of higher education services, and despite the importance of post-secondary education both to the social and economic development of the country and to the quality of life enjoyed by individual Canadians, very little research has been aimed squarely at increasing our understanding of the ways in which students actually experience university life and academic work. The subcultural and contextual meanings which at once produce and reflect varying levels of social and academic integration and of 'institutional fit' remain dramatically under-investigated. The lion's share of studies designed to document the background characteristics, aptitudes, interests, motivations and institutional and non-institutional experiences of university students has been American (Astin, 1977, 1985; Becker, Geer, \& Hughes, 1968; Boyer, 1987, 1991; Pascarella \& Terenzini, 1977; Tinto, 1982). In Canada, most student centred research has targeted specific sub-groups such as women (Thacker \& Novac, 1991; Williams, 1990), part-timers (Anisef, 1989), and drop-outs (Stewart, 1990; Gilbert, 1991), has focused upon such specific issues as participation (Guppy \& Pendakur, 1989), accessibility (Guppy, 1984; Gilbert \& Evers, 1989), and career goals (Nevitte, Gibbins, \& Codding, 1988), or has been historical (Axelrod, 1991). Other studies have been sponsored by departments of student services. Small in scale, these projects tend to focus on a narrow range 
of questions and issues. Little of this in-house research has been published (Gilbert, Gomme, Guppy, \& Macdonnel, 1991).

Other than Sid Gilbert's work at the University of Guelph (Evers \& Gilbert, forthcoming; Gilbert \& Pomfret, 1991; Gilbert, 1989; Gilbert \& Evers, 1989) and the research of Holdaway and Kelloway (1987) at the University of Alberta, larger scale studies of the typical undergraduate's experience in living and learning in the institutional environment of higher education are decidedly rare in Canada. Research of this nature is urgently needed in order that the micro-dynamics of the higher education experience can be better understood and that the delivery of educational services can be improved.

In an effort to redress the paucity of information on the undergraduate experience in Canadian institutions, this paper reports the initial findings of a study focusing on the quality of academic experience for students at a medium size postsecondary institution in eastern Canada - Memorial University of Newfoundland. In presenting this baseline data, our purposes are: 1) to set out the context in which undergraduates conduct their academic work; 2) to document what their experience entails and; 3) to present some of their perceptions of the higher education process. Specifically, we focus on students' entry traits, their reasons for attending, their academic work, their intellectual development, their paid work, and their experience with the student loans program. We also examine their interaction with and evaluation of faculty. We conclude with observations on their levels of satisfaction with service and on the levels of stress with which they must cope.

\section{Research Design}

The Memorial University of Newfoundland (MUN) has two campuses - a large main campus in St. John's (eastern Newfoundland) and a small college in Corner Brook (on the island's west coast). In the academic year 1990-1991, there were 12,472 full time students, 4,023 part time students, and 1,073 graduate students for a total enrollment of 17,568 (Burry, Hardy, Ludlow, \& Wolinetz, 1992). Memorial operates on a semester system, offering courses that typically involve 13 teaching weeks. Students in most cases must complete a minimum of 40 courses for a degree in Arts or Science. More courses are required of students in other programs such as Social Work (50) and Business (47). Memorial does not offer the equivalent of the three year degree option available at many other universities across the country (Memorial University Calendar, 1991-1992). Undergraduates' programs routinely span four or five years. 
During the fall semester of 1990 , exploratory unstructured interviews were carried out with a purposive sample of 12 undergraduate students. Based upon the initial interviews, a semi-structured interview schedule was constructed. Beginning in February 1991, semi-structured interviews were carried out with a random sample (a systematic sample with a random start) of 40 senior students majoring in Arts and Science. Initially, we randomly selected 10 male and 10 female students from each of the two faculties. Because there were so few females in Science outside of biology, we added to our sample all female respondents in the 'hard' sciences. There was only a handful. The response rate for the interviews exceeded $90 \%$.

The in-depth taped interviews (from 1 to 2 hours) produced detailed qualitative data both to be analyzed in their own right and to guide the development of the survey questionnaire. The third phase of the project involved the construction and administration of the survey instrument to a sample of students taking courses in Arts and Science. The survey segment of the project provided the data upon which this paper is based. All respondents were enrolled in courses on the main campus.

The sampling frame comprised the entire list of classes in Arts and Science offered during the most heavily subscribed slot in Memorial's timetable. This time slot (1:00-1:50 p.m.) was selected to maximize, at one point in time, the number of classes of various sizes at different year levels. The pool of classes was large enough to permit the selection of a stratified sample. Because all questionnaires were given out in the same slot, duplication of respondents was avoided.

Stratified by year level, 19 classes (about one third) were selected from the total of those offered in that slot. At the end of March 1991, questionnaires were distributed to all students in attendance on the designated day of classes. We returned to each class on subsequent days to hand out instruments to those absent during the initial distribution. We asked students to complete their questionnaires overnight. We returned to the classes to pick them up. The instrument contained 220 questions and concluded with the word 'Comments:' followed by a blank page. All verbatim quotes contained in this paper were volunteered under this prompt. Comments are edited for spelling and punctuation only. Neither style nor content is altered.

The response rate for the survey was $60 \%$ and yielded 388 usable forms. Given the length of the instrument ( 220 questions) and the time of year (just before the end of classes), we were satisfied with the number of returns. A significant limitation of our survey is the unavoidable exclusion of absentees. It 
may be that absentees represent a unique subset of students with particular characteristics in terms of motivation, ability, paid work commitments, performance capabilities, and the like.

\section{Findings}

\section{Student Characteristics}

Forty-two percent of the sample are male and $58 \%$ are female. The average age of respondents is 21 and most are within three years of that mean. The vast majority $(92 \%)$ is single with only $7 \%$ married or 'quasi-married.' The remaining $1 \%$ is divorced, separated, or widowed. Almost all $(99 \%)$ of the sample are full-time students. Twenty-eight percent are enrolled in Arts and 35\% are enrolled in Science. Twenty-nine percent of the sample, the majority of whom was taking arts courses as electives, identified themselves as belonging to other Memorial faculties (general studies, education, nursing etc.). Only $8 \%$ indicated no faculty affiliation. In terms of stages in their undergraduate careers, $40 \%$ had completed fewer than 16 courses, $24 \%$ between 16 and 25 courses, $18 \%$ between 26 and 35 courses, and $17 \%$ had completed 36 or more courses. Fewer than $1 \%$ were in their first semester and had completed no courses. The majority of undergraduates reports taking four or five courses $(83 \%)$. Thirty-five percent report grade averages in the $C$ range and $44 \%$ indicate grade averages in the $\mathrm{B}$ range. The remainder, in roughly equal proportions, identify themselves as $\mathrm{D}$ or $\mathrm{A}$ students.

In terms of living arrangements, $14 \%$ live in residence, $46 \%$ reside with their parents, $28 \%$ live off campus alone or with friends, $7 \%$ live off campus with a spouse or partner, and $5 \%$ have other forms of accommodation. Only $2 \%$ of the undergraduates surveyed report having dependent children. In these cases, the average age of the youngest dependent child is seven years.

For almost half the students, parents' education is limited to high school completion or less ( $43 \%$ fathers, $47 \%$ mothers). Twenty-eight percent of fathers and $27 \%$ of mothers have at least some experience in college, if not a college certificate. Twenty-nine percent of fathers and $26 \%$ of mothers have received at least some education at the university level. In terms of total parental income, $18 \%$ report less than $\$ 25,000,33 \%$ between $\$ 25,000$ and $\$ 44,999,18 \%$ between $\$ 45,000$ and $\$ 59,999$, and $31 \%$ over $\$ 60,000$. Seventy-seven percent report that their families are very encouraging of their attending university. 


\section{Reasons for Attending University}

Not surprisingly, the most important reasons for attending university relate to students' perceptions with regard to the link between higher education and the labour market. On average, eighty-four percent indicated that they are in university to further their chances of finding challenging, high paying, or interesting work upon graduation (three separate items). Seventy-nine percent agree with the observation that having a degree is essential to getting a good job in today's world. The next most important reasons cited for continuing on to university are getting a good general education (81\%), developing the ability to think for themselves $(58 \%)$, and finding out the nature of their interests (54\%). Of lesser importance were finding out what they are good at doing (42\%) and learning purely for its own sake $(41 \%)$. Of no real significance are reasons having to do with friends going on to university, social life on campus, meeting family expectations, and getting away from home.

\section{Academic Work}

Students indicate that they attend the majority of their classes. Eighty-one percent report attendance rates in excess of $90 \%$. The figure increases to $97 \%$ when the attendance level is lowered to $76 \%$ or more of their classes. Moreover, the large majority of undergraduates $(80 \%)$ sees attendance as important to their success in university.

At times when there are no tests in a course and no assignments due, students devote an average of 14 hours per week outside of class time to their studies. This number virtually doubles to an average of 27 hours during periods when tests are being given or when assignments are due. For both averages, the standard deviations are large ( 11 and 13 respectively), indicating a good deal of variation on this dimension across the student body. Sixty-one percent of respondents indicate that they consider their academic work load heavy, and a further $29 \%$ classify it as very heavy.

The vast majority of respondents shows considerable commitment to their university education. Ninety-one percent indicate that finishing their degrees is very important to them and $73 \%$ say that they would not forgo completion of the degree even if a good job were available to them before graduation.

\section{Perceived Development at University}

Respondents see their formal education as contributing most (a great deal) to the development of a desire to continue learning (49\%), to their working independently (44\%), and to their thinking and reasoning (43\%). Forty-two percent 
also indicate that their education is contributing a great deal to their development of expertise in a particular field of study. Thirty-nine percent, $37 \%$, and $36 \%$ respectively see their schooling as contributing to the development of abilities in time management, organization, and independent thinking. Students are rather more equivocal as to whether or not university education contributes much to their development in the areas of reading, writing, oral communication, decision-making, computational expertise, and understanding and appreciating science.

On the other hand, few undergraduates believe that formal education at the university level contributes a great deal to their appreciation of art, music, and literature (only $12 \%$ ), to their creativity (only 17\%), and to their understanding of global issues (only $21 \%$ ).

\section{Contact with Professors}

For the most part, there appears to be limited contact outside of class between professors at Memorial and their students. When students do approach professors outside of class, they do so to discuss a course-related problem (90\%), to review an assignment or exam returned by a professor $(71 \%)$, or to get advice about academic programs $(61 \%)$. On these three items, an average of $70 \%$ report talking to a professor for more than five minutes either not at all or only once or twice in a semester. Furthermore, a very large majority of undergraduates indicates never speaking to a professor outside of class for more than 5 minutes about personal problems $(94 \%)$ or about campus issues $(88 \%)$. It is more than likely, however, that students see no reason to seek out their instructors for these reasons. Still, $84 \%$ report no contact whatsoever for the purposes of informal socializing, $60 \%$ report no contact whatsoever to discuss issues concerning their future careers, and $49 \%$ report no contact whatsoever to discuss intellectual matters.

When asked about how many professors they had contact with for five minutes or more in order to discuss something other than a problem such as grades, exam times, and due dates, a third (32\%)indicate no contact whatsoever, $24 \%$ indicate contacts with one professor, $37 \%$ indicate contacts with two or three professors, and only $7 \%$ indicate discussions with four or more of their professors. Principal reasons for not initiating more in the way of contact involve students' lack of confidence or not knowing the system on one hand and their perceptions of professors as uninterested, uncaring, or too busy on the other. The following comments were typical: 
...some people find it really nerve racking to even speak to the prof, not because they are unapproachable, but simply because of their own insecurities. For me, I prefer to go to class and handle the rest on my own.

My entrance into university was a difficult one. I was very unfamiliar with St. John's as well as with the university procedure. Although many help facilities were available to me, I was unaware they existed when I needed them. I never knew where to go for help.

I find the majority of MUN's profs totally unapproachable.

With regards academic advice, I do not think profs are sincerely interested.

Most of the first year coordinators (the ones I've had the pleasure of dealing with) are heartless assholes.

\section{Quality of Teaching and Learning}

On the basis of total courses taken during the past three semesters, we asked undergraduates to indicate the exact number of courses that met certain specified criteria. The percentages were then calculated and averaged across all students who provided responses to these questions. Percentages represent the proportion of courses taken that met each criterion.

Students report that in $57 \%$ of their courses the content was interesting and that in $58 \%$ the work was intellectually challenging. Fifty-nine percent of courses required extensive study outside of class and students indicate that the work load was heavy in $53 \%$. In $43 \%$, students claimed that it was hard to get good marks.

According to our respondents, professors put a lot of effort into their teaching in $52 \%$ of the courses taken. The professor had high expectations regarding student performance in $48 \%$ and encouraged students to think independently in $47 \%$. In $43 \%$ of courses, the professor encouraged student participation. Professors tried to make students feel comfortable expressing themselves in $43 \%$ of courses. Respondents indicate that their professors valued student opinions in $43 \%$ of courses and that they went out of their way to help students in $38 \%$. They report that professors provided extensive feed-back on work submitted by students in $33 \%$ of their courses.

Undergraduates rated their professors performances as outstanding in $27 \%$ of their courses, as competent in $57 \%$, and as unacceptably poor in $18 \%$. The 
'some are good, some not so good' sentiment is nicely encapsulated in the following observation by one of our respondents:

Since I have been here at MUN, five or six profs I have had a course with shouldn't even been teaching here. Only three have been exceptionally good and the rest I can live with their teaching.

\section{Paid work}

A sizable minority of the sample (36\%) reports holding down a paid job during the term. The average hourly wage is $\$ 7.13$ with a standard deviation of $\$ 3.64$. On average, students report working about 13 hours a week. The standard deviation is large ( 9 hours) suggesting considerable variation across the student body. With reference to the term in which the survey was administered, a majority of students $(63 \%)$ indicates that their earned incomes are $\$ 1,000.00$ or less $(88 \%$ earned $\$ 2,000.00$ or less). For the year $1991,68 \%$ of students report incomes from paid work of $\$ 4,000$ or less.

While $47 \%$ report enjoying their paid work, a significant minority (17\%) says that they do not find this facet of student life particularly pleasant. When asked about the extent to which their paid work interferes with their academic work, $(62 \%)$ confess that it does. Of those who are holding down jobs, $67 \%$ indicate that this work is very essential to their being able to continue in school. In this regard, one student remarked,

My student loan is adequate to pay for tuition and books but if I did not have a job it would no longer be enough to see me through the semester.

\section{Student Loans}

Fifty-two percent of the respondents have student loans either from current or from past semesters. The loans are rated as hard to get by $49 \%$. On this dimension, students made comments like the following:

I wish it were a little easier to get a student loan. I live at home and therefore cannot get a loan. Hence, I must work part-time for pocket money etc... despite the heavy course load in the Business Cooperative Program. I would be quite willing to pay back loans once I have a full-time career. The little extra money now would mean a lot since the small amount I can make working part-time takes away from my study time.

....you assume that parents can afford to send children to university. My parents have a fairly high income but because of circumstances 
like moving to a new location, building new home etc. they are short on money now. Student loans are based on past income not present situation. Because of this I could not get a loan and I am now in danger of not being able to continue education unless I can find a job to pay for next year's finances - $\$ 6,000-8,000$.

Loans are seen to be insufficient to meet financial needs by $71 \%$ and as unfairly given out by $61 \%$. As one student from a large family with one parent deceased and the other unemployed put it:

In my community, summer work is hard to find. Last term I ended up getting a personal loan because they only gave me $\$ 1,000$ loan and no grant. If I don't deserve to get financial help, who does? With education fees rising as they are I personally do not know if I could afford to come back here.

Of those who have loans, $83 \%$ report that the loan income is absolutely vital to their staying in school.

By graduation, of respondents with loans, a quarter (26\%) estimate that they will owe in excess of $\$ 20,000$. On the other end of the scale, a quarter (26\%) will owe $\$ 10,000$ or less. The remainder, $48 \%$ estimate their debt at between $\$ 10,001$ and $\$ 20,000$. Forty-one percent anticipate difficulty paying back their loans and $62 \%$ express concern about the debt that they are incurring. Nonetheless, $67 \%$ see the loan as a good investment in their future.

\section{Levels of Satisfaction}

Many aspects of the student experience (development, contact with professors, etc.) are affected by the personal preferences and the subsequent choices made by the undergraduates themselves. For this reason, we asked a series of questions intended to determine the students' levels of satisfaction with various aspects of undergraduate life.

Over $60 \%$ of undergraduates indicated that they were dissatisfied with the loans program, with available work space on campus, and with the opportunity to evaluate their professors. The latter point seems to be a particularly sore one. As one student put it:

There are many "good" profs and there are some "bad" ones. They need to be weeded out! Students should evaluate each professor at end of semester.

Between $50 \%$ and $60 \%$ were dissatisfied with the amount of contact that they had with professors and with the university's administration procedures. The amount and quality of academic advising, the relevance of course content 
to the job market, and class size were indicated by between $40 \%$ and $49 \%$ as sources of dissatisfaction. On the issue of class size, typical comments were of the following variety.

I find the sizes of my classes appalling. In my genetics class, there are $150+$ and in organic chem, $50+$.

Roughly a third of students were dissatisfied with the quality of contact with professors, the selection of available courses, the workload in courses, and the physical education facilities. Approximately a quarter of students expressed dissatisfaction with the interest levels and content of their courses, with their marks, and with the teaching performances of their professors and teaching/lab assistants. It is of some interest that students were more favourably disposed toward the teaching of the latter than of the former. Students indicated the least dissatisfaction with the following items: the amount being learned, the library resources, their social lives, and their accommodations.

\section{Stress}

To construct a more accurate picture of the kinds of stresses and strains produced by these dissatisfactions and by other aspects of the undergraduate experience, we asked respondents to indicate the extent to which certain aspects of university life and academic work place them under pressure and cause them to experience strain. The following remark sets the scene for this discussion:

I feel that students in university feel a lot more pressures than we give them credit for. If we're studying at university we're 'taking it easy,' 'relaxing' for a few years before we go out and do 'real work.'

In response to the extent to which certain aspects of the undergraduate experience produced strain, students could indicate 'no strain', 'moderate strain' or 'severe strain.' The following percentages refer to the severe categories only. Consequently, we are understating the levels of expressed strain to some extent.

Sixty percent or more report feeling severe strain over being able to get high enough marks and, for those in need, over getting an adequate loan. Over $50 \%$ indicate that meeting expenses placed them under severe pressure. Over $40 \%$ cite meeting academic expectations, handling the work load, balancing job responsibilities with the demands of school, and finding enough time to study as sources of severe pressure. For over $30 \%$, getting courses, finding work, coping with crowding, and meeting professors' standards caused them to feel severe strain. Meeting family obligations, coping with living conditions, doing university level work, and finding accommodation were less stressful, being cited as a severe strain by between $20 \%$ and $29 \%$. Making friends and balancing social 
activities with school work were least stressful. Many of the comments written on the questionnaire alluded to three problem areas - workload, crowding, and of course, money.

On workload:

I find that many science courses, especially those like genetics, which have labs related with them are really like two courses in one. Often, labs are a course in themselves. There is not enough time in the week to do all the lab reports, write-ups, assignments and study for tests at a relaxing pace.

It has been go, go, go from about the third week of classes! I find it very stressful - panic attacks often hit me while worrying about tests and finals etc. It's also hard to organize my study time the way I would like it. I am a second year student and my GPA right now is 2.5 but sometimes I wonder why I am here (when I get a low mark or workload seems too much). I often compare myself with others who get higher marks and that's a real downer too. I feel that I don't have enough time to really learn the courses I do thoroughly enough to carry their content with me from semester to semester. Often, what I learn in one semester becomes a total blank right after the set of finals for that semester is done!

\section{On crowding:}

Also, overcrowded classrooms and libraries don't make for good learning. It creates isolation and a feeling of powerlessness and helplessness.

This university is severely overcrowded. Many days I am unable to find a place to sit down to eat my lunch.

\section{On money:}

I hope that you consider that even if a person is working it is still extremely hard to make ends meet. If students live out of town they usually travel back and forth on the bus which is expensive! If they have a car, there's gas and maintenance. A lot of people live too far away to walk. You also must consider social events such as movies (\$7.50 each). These things are practically necessities. After all, no matter how dedicated a person is, they must take time out to relax and unwind. Even Christmas presents are a headache. Some students don't give presents because they can't afford it but most like to give their family a little something. With increased taxes and general 
inflation it's hard to make ends meet. University and social life cannot co-exist comfortably.

My spouse and I are being greatly affected by provincial cutbacks. My husband had been laid off and it will be very difficult for me to continue my education. He has a Math degree and Education degree and this is not very encouraging for me. I am currently trying to find work at the university for the summer so I can save money to return to school in September. As far as I can see, in order for me to continue my education, my husband will have to leave the province while I remain here in St. John's. As much as I would love to remain in Newfoundland after I graduate, I refuse to continue this roller coaster ride with our government!

....you cannot fulfill academic requirements to your greatest ability nor can you enjoy university life (to some degree) when you are worried about not having enough food to eat or a place to live.

Next year I am going to have to apply for a loan and I am shit baked that I won't receive enough money to attend university full time Fall '91. My sisters started university and now my parents can't help me with the cost. (They usually pay for one semester and I pay for the other.)

I enjoy university a lot but I fear my younger brother will not have the same privilege to go as myself. It is just too expensive. Sometimes I do not have enough money for food. It then becomes necessary to rely on my parents who are by no means rich.

\section{Doing it over}

The final section of the questionnaire contained items that asked students to reflect upon their university experiences to date and to provide us with some insights into what they would do differently if they could start over. The vast majority (70\%) confess that they would study harder. Sixty-three percent believe that they would make more effort to get academic advice and $44 \%$ report that they would try harder to get to know their professors better. Thirtythree percent feel that they would have liked to become more involved in the social aspects of university life. Only $12 \%$ say that they would choose a different major and only $15 \%$ indicate that they would attend a different university. Fewer than 5\% report that they would go to community college instead of university and fewer than $8 \%$ say that they would work for a time between finishing 
high school and going into postsecondary education. Finally, only $4 \%$ indicate that they would not go on to postsecondary education.

\section{Conclusion}

This paper has presented findings on the experiences and perceptions of Arts and Science undergraduates at a relatively large Canadian university. The vast majority of the students in the sample was enrolled full time and was aged 18 to 24. These characteristics represent the lion's share of university students studying in Canada today. It is for this reason that this research provides data of special interest and relevance to administrators, to student services personnel, and to faculty members at this university and at other institutions of similar size. The findings identify areas in which universities might improve their delivery of services to students. In the process, the research informs the design and implementation of policy aimed at constructive change. At the very least, the data should sensitize constituent groups, especially faculty, to the very real problems with which many of today's 'typical' undergraduates must cope.

While most students enroll in postsecondary educational programs with vocational goals in mind, they are also keenly interested in acquiring a solid general education. According to our data, undergraduates are a sincere and dedicated lot. They attend most of their classes, they are heavily committed to completing their programs, and they work quite diligently in pursuit of their goals in the face of what many of them consider to be heavy workloads. Our undergraduates are not, however, completely satisfied with the services that they receive. While satisfaction levels vary with the type of services provided, it is clear that there does exist substantial room in which institutions can make improvements. Universities could, for example, do a better job of ministering to the needs of students in the areas of teaching and instructional evaluation, class sizes and faculty-student interaction, academic advising, and student finances.

Student finances are particularly problematic. About half of our sample was involved in the student loans program. Of those with loans, most report that funds from this source are absolutely vital to their remaining in school. Nonetheless, most also report that loans have been hard to get in the past and will be hard to repay in the future. Debt was a significant source of concern among our respondents. Over a quarter indicated that they will owe in excess of $\$ 20,000$ upon graduation. Despite these concerns, students view the financial investment in their own futures in positive terms.

The need for funds also translates into a necessity to undertake part-time employment. About a third of our sample worked in the paid labour force to 
support their education. Most cited this source of income as crucial to their continuation in university and most admitted that part-time work, though essential, did interfere with their studies.

Finances aside, our data suggest that students experience disturbingly high levels of stress. The 1990's mark an era where postsecondary students, perhaps more than ever before, have heard the human capital call to arms. They have got the message loud and clear and they are heeding it well. A university degree is the principal means by which they can acquire the knowledge, the skills, and the certification necessary for entry into an increasingly competitive job market. Challenging work, a rewarding job and 'the good life' are contingent upon, at a minimum, the attainment of postsecondary qualifications. In addition to finances and being able to stay in school, students cite as sources of stress, demanding workloads, crowded conditions, and overtaxed facilities. In the face of these impediments, it is not surprising that they also express concern over being able to perform at levels sufficiently high to meet the standards required both by the university and by prospective employers reviewing their transcripts.

It is not without justification that Canada's young people link the university degree to a better job. Nor is it without good reason that they make the connection between good jobs and a higher quality of life later on. Governments and universities have long recognized these links and they have advocated socially just policies of accessibility in order to facilitate the more equitable distribution of social and economic rewards in Canadian society.

In recent years, highly accessible institutions like Memorial have been greeted with massive influxes of students in rational pursuit of their worthy aspirations. The inflation, recession, and government under-funding characteristic of these same years have not been without impact, however. Students trying to finance their education find that loans are not adequately indexed. For many, part-time work and summer jobs are necessary; but at the same time levels of youth unemployment, particularly in a province like Newfoundland and Labrador, are high. Once at school, they find the university itself suffering pecuniary pains. These travails are inevitably passed along to undergraduates in the form of large classes, campus crowding, and overtaxed resources (libraries, physical education facilities, counselling programs, and the like).

Policies promoting universal accessibility (once dear to Memorial's institutional heart) broadened the range of the student body in terms of demographic traits, cultural backgrounds, interests, and abilities. Observers, both within the system and beyond its boundaries, continue to complain about ongoing deterioration in the quality of the student body and about declining standards of 
performance. They contend that increasing numbers of students 'do not belong in university.' It must be recognized, however, that in the face of growth and diversity in numbers of students little if anything has been done to alter institutional practices in such a way as to meet the needs of the new clientele more adequately.

The most straightforward and therefore preferred attack on the problems of oversubscription and under-funding is two-pronged. Raise admission standards. Increase fees. Memorial, like many universities across the country, is implementing both strategies (Bennett, Byrne, Gardner, \& Wilson, 1992). These tactics may well limit enrollments, but they will do little to help many of our students, even the more talented ones. We suggest that a better approach would be to consider seriously restructuring institutions of higher education to address meaningfully student concerns and to meet their learning needs more adequately. We do so recognizing that this strategy flies in the face of economic rationality, professional vested interest, and a tradition emphasizing research over teaching.

\section{References}

Anisef, P. (1989). Studying part-time in Canada's universities: A social change perspective. Canadian Journal of Higher Education, 19, 11-28.

Astin, A. (1977). Four critical years: Effects of college on beliefs, attitudes, and knowledge. San Francisco: Josey Bass.

Astin, A. (1985). Achieving educational excellence. San Francisco: Josey Bass.

Axelrod, P. (1991). Making a middle class: Student life in English Canada. Montreal: McGill Queen's Press.

Becker, H., Geer, B., \& Hughes, E. (1968). Making the grade: The academic side of college life. New York: Wilcy.

Bennett, G., Byrne, J. Gardner, G., \& Wilson P. (1992). Report of the University Task Force on Admission Policy. St. John's: Memorial University of Newfoundland.

Bloom, A. (1987). The closing of the American mind. Ncw York: Simon and Schuster.

Boyer, E. (1987). College: The undergraduate experience in America. New York: Harper and Row.

Boyer, E. (1990). Scholarship reconsidered: Priorities of the professoriate. Princeton, NJ: Carnegie Foundation for the Advancement of Teaching.

Burry, J., Hardy, D., Ludlow, W., \& Wolinetz, S. (1992). Vice-President Academic Task Force on Readmission and Continuance Policies Report. St. John's: Memorial University of Newfoundland.

Evers, F., \& Gilbert, S. (1991). Outcomes assessment: How much value does university education add? Canadian Journal of Higher Education., 2l(2), 53-76.

Gilbert, S. (1989). The forgotten purpose and the future promise of university education. Canadian Journal of Community Mental Health, 8, 103-122. 
Gilbert, S. (1991). Attrition in Canadian universities. Ottawa: Commission of Inquiry on Canadian University Education.

Gilbert, S., \& Evers, F. (1989). Accessibility and quality in higher education. The Services Industries Journal, 9, 44-62.

Gilbert, S., \& Pomfret, A. (1991) Gender tracking in university programs. Ottawa: Ministry of Industry Science and Technology.

Gilbert, S., Gomme, I., Guppy, N., \& Macdonnel, A. (1991). Measurement of work related student outcomes. Research proposal Social Sciences and Humanities Research Council of Canada.

Guppy, N. (1984). Access to higher education in Canada. Canadian Journal of Higher Education, 14, 79-93.

Guppy, N., \& Pendakur, K. (1989). The effects of gender and parental education on participation within post-secondary education in the 1970's and 1980's. Canadian Journal of Higher Education, 19, 49-62.

Holdaway, E., \& Kelloway, K. (1987). First year at university: Perceptions and experiences of students. Canadian Journal of Higher Education, 17, 47-63.

Nevitte, N., Gibbins, R., \& Codding P. (1988). Career goals of female science students in Canada. Canadian Journal of Higher Education, 18, 31-48.

Pascarella, E., \& Terenzini, P. (1977). Patterns of student-faculty informal interaction beyond the classroom and voluntary freshman attrition. Journal of Higher Education, 48, 540-562.

Ranking universities: Maclean's will publish another special issuc. (1992, June 16). McMaster Courier Vol. 11, Num.11, p. 3.

Smith, P. (1991). Killing the spirit: Higher education in America. New York: Penguin.

Smith, S. (1991). Report: Commission of inquiry on Canadian university education. Ottawa: A.U.C.C.

Stewart, M.J. (1990). Attrition from health professional schools in a Canadian university. Canadian Journal of Higher Education, 20, 43-64.

Sykes, C. (1988). ProfScam: Professors and the demise of higher education. Washington, DC: Regnery Gateway.

Thacker, C., \& Novac, M. (1991). Student role supports for younger and older middle aged women: Application of a life event model. Canadian Journal of Higher Education, 21, 13-36.

Tinto, V. (1982). Limits of theory and practice in student attrition. Journal of Higher Education, 53, 687-700.

Webster, W.G. (1990). Quality assurance: A framework for Canadian universities. Canadian Journal of Higher Education, 20, 75-85.

Williams, D. (1990). Is the post-secondary classroom a chilly one for women? Canadian Journal of Higher Education, 20, 29-42. 